\title{
Natural Intellectual Property Rights and the Public Domain
}

\author{
Hugh Breakey*
}

No natural rights theory justifies strong intellectual property rights. More specifically, no theory within the entire domain of natural rights thinking - encompassing classical liberalism, libertarianism and left-libertarianism, in all their innumerable variants coherently supports strengthening current intellectual property rights. Despite their many important differences, all these natural rights theories endorse some set of members of a common family of basic ethical precepts. These commitments include non-interference, fairness, non-worsening, consistency, universalisability, prior consent, self-ownership, selfgovernance, and the establishment of zones of autonomy. Such commitments have clear applications pertaining to the use and ownership of created ideas. I argue that each of these commitments require intellectual property rights to be substantially limited in scope, strength and duration. In this way the core mechanisms of natural rights thinking ensure a robust public domain and categorically rule out strong intellectual property rights.

If intellectual property rights are truly formed for a nonutilitarian purpose, asks James Boyle pointedly, why should they expire? ${ }^{1}$ Why indeed? Boyle's rhetorical question expresses a

\footnotetext{
* Political Philosophy and TC Beirne School of Law, University of Queensland, Australia. Thanks to Julian Lamont and Robert Burrell for invaluable input and critique. I am grateful also to the editor and the anonymous reviewers at the MLR for their helpful comments.

${ }^{1}$ J. Boyle, The Public Domain: Enclosing the Commons of the Mind (New Haven: Yale University, 2008) 29. Note: my concern in this article is with all and only theories of natural rights ('entitlement' theories). I do not engage with alternative justifications for strong intellectual property rights as might be made on the basis of,
} 
widespread sentiment in intellectual property commentary and in the burgeoning literature on the public domain. Legal commentators, theorists and historians routinely characterise the ongoing legal controversy in intellectual property as being a contest between weak, utilitarian privileges, and strong, natural property rights. ${ }^{2}$ This characterisation is even starker in popular discourse, where natural justice appears as a force perennially recommending a shift just a little to the right of where we are now - wherever 'where we are now' happens to be. ${ }^{3}$

Yet there is a puzzle here. The overwhelming majority of natural rights treatments of intellectual property in the last several decades have consistently called for increased limitations on the scope, strength and duration of intellectual property. ${ }^{4}$ Why has this preponderance of opinion failed to persuade commentators, lawyers and judges? The reason appears to be simply this: the natural rights reasons for limitations on intellectual property

say, utility or efficiency. By 'intellectual property rights' I refer primarily to copyright, patent and designs law, though at times there may be application to other parts of intellectual property law, including trademark, the right of publicity, and plant protection acts.

${ }^{2}$ See eg: P. Goldstein, Copyright's Highway: From Gutenberg to the Celestial Jukebox (New York: Hill \& Wang, 1994) 11-17; B. Friedman, 'From Deontology to Dialogue: The Cultural Consequences of Copyright' (1994-5) 13 Cardozo Arts and Entertainment Law Journal 157, 160; L. Patterson and S. Lindberg, The Nature of Copyright: A Law of Users' Rights (Athens, Ga.: University of Georgia, 1991) 109-110, 120, 141-152; Re history, see M. Rose, Authors and Owners: The Invention of Copyright (London: Harvard University, 1993) 6982; R. Deazley, On the Origin of the Right to Copy: Charting the Movement of Copyright Law in EighteenthCentury Britain (Oregon, USA: Hart, 2004) 42, 140-143, 158-164; R. Deazley, Rethinking Copyright: History, Theory, Language (Cheltenham: E. Elgar Publishing, 2006) 31-39, 49-55, 64; see also the famous characterisation by Samuel Johnson in J. Boswell, Boswell's Life of Johnson (Oxford: OUP, 1953) 546-547. ${ }^{3}$ See, eg, the discussion in Boyle, $n 1$ above, 33-34. Recent arguments in favour of the UK copyright term extension in sound recordings were thick with refrains of 'fairness', 'taking', 'desert' and 'just reward'. ${ }^{4}$ See authors referenced nn 7-12 below. The shared template for most contemporary analyses of natural intellectual property rights is J. Locke, Two Treatises of Government (New York: Hafner, 1947) esp Bk II ch 5. 
can appear both controversial and ambiguous. As a result, natural rights theories seem overly plastic, capable of being manipulated, interpreted and construed in ways that can create all sorts of diverse conclusions. ${ }^{5}$ Worse, the project of limiting the claims of property can seem an uphill battle in natural rights paradigms, as marginal aspects of natural rights thought need to be deployed against the strong, natural property rights that hold default status. ${ }^{6}$

These worries have a point. There is no conceptual necessity for a natural rights theory to adopt, for instance, Locke's spoilation proviso, ${ }^{7}$ his social-utility considerations, ${ }^{8}$ his construal of labour, ${ }^{9}$ his way of delineating the transformation of natural property upon entry to civil society, ${ }^{10}$ or even to accept the general natural-law constraints on the nature of owned objects. ${ }^{11}$ Moreover, specific interpretations of natural rights thinkers, no matter how

\footnotetext{
${ }^{5}$ R. Burrell and A. Coleman, Copyright Exceptions: The Digital Impact (New York: CUP, 2005) 104; Boyle n 1 above, 261.

${ }^{6}$ C. Craig, 'Locke, Labour and Limiting the Author's Right: A Warning against a Lockean Approach to Copyright Law' (2002-03) 28 Queen's Law Journal 1, 55.

${ }^{7}$ E. Hettinger, 'Justifying Intellectual Property' (1989) 18 Philosophy and Public Affairs 31, 45; P. Drahos, A Philosophy of Intellectual Property (Hampshire: Ashgate, 1996) 51.

${ }^{8}$ J. Hughes, 'The Philosophy of Intellectual Property’ (1988-89) 77 Georgetown Law Journal 287, 319-320.

9 ibid 301-311. Hughes inventively uses his notion of labour to justify the idea-expression distinction.

${ }^{10}$ Friedman, n 2 above, 162-167.

${ }^{11}$ This move typically emphasises the non-rivalrous nature of ideas: their capacity to be used without conflict by everyone. See T. Palmer, 'Are Patents and Copyrights Morally Justified? The Philosophy of Property Rights and Ideal Objects' (1990) 13 Harvard Journal of Law and Public Policy 817, 855-861; J. Cahir, 'The Moral Preference for DRM Ordered Markets' in Fiona Macmillan (ed), New Directions in Copyright Law (Cheltenham: Edward Elgar, 2005) 24, 43-44. Re limitations arising from the beginning of natural law in Greece and Rome: A. Yen, 'Restoring the Natural Law: Copyright as Labor and Possession' (1990) 51 Ohio State Law Journal 517, 522-524. Re later natural law theorists such as Grotius and Pufendorf: H. Mitchell, The Intellectual Commons: Toward an Ecology of Intellectual Property (Lanham, Md: Lexington Books, 2005) ch's. 6, 8. Re Locke: G. Sreenivasan, The Limits of Lockean Rights in Property (New York: OUP, 1995) 99; R. Grant, John
} 
attractive, ${ }^{12}$ always leave open the possibility that perhaps a slightly different yet cognate interpretation - emphasising some parts of the theory at the expense of others - would yield quite different conclusions. Bolstering this concern is the presence of at least some natural rights thinkers - including Lysander Spooner and Adam Moore - offering arguments for stronger intellectual property rights. ${ }^{13}$

Given these concerns it seems reasonable to suppose there is at least one star in the constellation of existing natural rights theories justifying strong intellectual property rights. I argue there is no such star. The prohibition against strong intellectual property rights arises from the most basic machinery of an entitlement regime as it applies to ideas. The result is secured by the very first questions that natural rights theories of all ilk will immediately put to any proposed right: Is it universalisable? Does it worsen the prior position of others? Is it consistent with others' rights? Does it grant powers to impose new duties without prior consent? Can such duties be imposed across property boundaries? Do they interfere with the basic natural rights reasons for having property in the first place? These questions reflect foundational parts of natural rights perspectives and they inevitably shape intellectual property rights just as they shape all other natural rights. Together they provide the most straightforward answer imaginable to Boyle's challenge: Why are natural intellectual

Locke's Liberalism (Chicago: University of Chicago Press, 1987) 113. Similarly: T Jefferson, 'Thomas Jefferson to Isaac McPherson' in A. Lipscomb and A. Bergh (eds) The Writings of Thomas Jefferson (1905) Document 12, Article 1, §8, Clause 8; Marquis de Condorcet, 'Fragments concerning freedom of the press' (2002) 131 Daedalus 57.

12 The classic example remains W. Gordon, 'A Property Right in Self-Expression: Equality and Individualism in the Natural Law of Intellectual Property' (1992-93) 102 Yale Law Journal 1533.

${ }^{13}$ L. Spooner, The Law of Intellectual Property (Boston: Bela Marsh, 1855); A. Moore, Intellectual Property and Information Control: Philosophic Foundations and Contemporary Issues (New Brunswick: Transaction Publishers, 2001). 
property rights limited? Because other people have rights too. Doubtless natural rights theories place the individual front and centre. But that is not the same thing as saying they place the author front and centre. A natural rights theory focused primarily on the rights of authors is as nonsensical an intellectual construct as a utilitarian theory that counted primarily the happiness of florists.

Since my intent is not to show that some specific natural rights theory mandates a robust public domain, I largely eschew discussion of the various particular justifications (labour, ${ }^{14}$ personality, ${ }^{15}$ and so on) that might be put forward for natural intellectual property rights. Rather, I argue that a robust public domain can be secured by considerations that apply to the nature of natural rights as such. Such taproot commitments include consistency in application, non-interference, fairness, non-worsening, universalisability, prior consent, selfgovernance, and the establishment of zones of autonomy. ${ }^{16}$ To be sure, not all natural rights theories accept every one of this family of ethical precepts and conditions, ${ }^{17}$ but they all

\footnotetext{
${ }^{14}$ I discuss a key labour-based argument at text to nn 36-37 below.

${ }^{15}$ Though see $\mathrm{n} 17$ below.

${ }^{16}$ For explanation of each of these natural rights commitments and their relationship to the public domain, see, severally: non-interference: text to $\mathrm{nn} 38-41,69,101,125$; fairness: text to n 68 ; non-worsening: text to nn 69 , 73-76, 91; consistency of application: text from n 42; robust universalisability: text from n 66; prior consent: text to $\mathrm{n} 95$; self-governance: text to nn 44-45, 71; self-ownership: text to $\mathrm{nn} 44-45,96,117-124$; zones of autonomy (private property rights): their structure: text to nn 93-116; their natural rights justifications: text to $\mathrm{nn}$ 89-92.

${ }^{17}$ Since below I refer to labour-based arguments in particular, and Lockean perspectives in general, it is worth illustrating the ways these several large-scale conditions appear in arguments for natural intellectual property rights made on the basis of personality (as we find in Hegel, for instance). Hegel's intellectual property rights meet the conditions of (a) consistency, (b) robust universalisability, (c) domains of autonomy (tangible property rights) and (d) self-ownership. Re (a): all systems of natural rights must commit to a basic condition of consistency in application, and Hegel's intellectual property rights (outlined in G. Hegel, Philosophy of Right,
} 
accept some subset of this group. ${ }^{18}$ I argue that each and every one of these premises proscribes strong intellectual property rights. I additionally draw upon several other commitments that are close travelling partners to natural rights theories. These considerations include the natural right to free speech, the right to privacy, the encouragement of independent, entrepreneurial activities, distaste for large-scale bureaucracies, a general approbation of the free-market, and a commitment to the development of science, learning, rationality and culture.

The argument proceeds as follows. In the following section I outline five core mechanisms constraining the scope, strength and duration of intellectual property rights. Each of the subsequent four sections argues that different natural rights commitments independently require intellectual property rights to be limited on each of these three dimensions. I begin by noting the perennial natural rights commitment to freedom from interference does not justify strong intellectual property rights in the same way it prima facie justifies strong tangible property rights. In the following section I show that consistent application of strong intellectual property rights introduces tensions with several separate natural rights commitments - perhaps the most important being the consequences for self-ownership created by the unilateral imposition of enforceable debt. Next I turn to consider the natural rights commitment to a robust, opportunity-preserving sense of universalisability, a condition

trans T. Knox (Oxford: Clarendon, 1952) 40-56) are no exception. Re (b): Hegel's discussion of the rights of learners and future creators who engage with the copyrighted/patented product ensure robust universalisability (especially given Hegel's view that 're-thinking the thoughts of others is learning too' ibid 55; on the natural dissolution of Hegelian intellectual property rights ibid 52). Re (c) and (d): Hegel primarily used his personhood argument to justify both tangible property rights (ibid 40-53) and self-ownership (ibid 43-48), and he was explicitly aware of the need to assimilate his intellectual property rights with these commitments (ibid 55).

${ }^{18}$ Below (text to nn 126-133) I argue there are powerful reasons for natural rights theories to accept at least one (if not both) of the commitments to self-ownership and robust universalisability. 
sometimes expressed in terms of fairness and non-worsening. I show in two ways how robust universalisability rules out strong intellectual property rights. The final section demonstrates why natural rights libertarians must reject strong intellectual property rights. Four separate arguments are marshalled in this section, drawing on the libertarian commitments to the free market, to private property rights (including separate concerns with both their justification and their nature), to free-speech, and to self-ownership. Each commitment imposes the required limits on intellectual property.

Every one of the various natural rights commitments put forward operates more or less independently of the others in constraining intellectual property rights. The argument is thus intended to achieve a substantial degree of redundancy; the securing of a robust public domain in any given natural rights theory typically will be over-determined by the base-level commitments of that theory. Notwithstanding this over-determination, I complete the argument by emphasising the importance to natural rights thinking of two commitments in particular: robust universalisability and self-ownership. Drawing a link to modern theories of rights, I suggest that there is good reason to think that no natural rights theory can at once eschew both commitments (that is, eschewing one of the pair may be viable, rejecting both is not). These two mechanisms operate as sheet anchors in natural rights thought, and their combined dissolution by strong intellectual property rights is, I argue, as unacceptable as a natural right to found state-religions.

Ultimately, far from countenancing strengthened intellectual property rights, natural rights perspectives have a wealth of reasons to be already dissatisfied with the current levels of state-interference, bureaucratisation, unilateral duty-imposition, failure of equal opportunity, weakened tangible-property rights, abridgments of self-ownership, and impediments to selfgovernance. 


\section{The public domain provisions}

By the public domain I refer to that substantial swath of ideas and information situated in a broad public milieu. ${ }^{19}$ These ideas are freely available or otherwise reasonably accessible to almost all citizens, and upon such ideas they may act, invent, critique, converse, produce and play. ${ }^{20}$ In modern Western polities, it is possible to point to five key provisions that conduce to the preservation of the public domain. In what follows I will take it that an intellectual property regime strongly upholding the following five provisions allows a robust public domain, and I stipulate strong intellectual property rights (hereafter strong IPR) as any proposed set of natural rights systematically derogating one or more of these five provisions.

Three prefatory points: first, the provisions are not an all-or-nothing affair when it comes to their contribution to a flourishing public domain. They work together to produce an overall effect - allowing individuals the capacity to learn, think, talk, create and act on the basis of the ideas, artefacts and activities suffusing the world around them. Such capacities are not sundered simply because there is a limited breach of one of the provisions. ${ }^{21}$ However, any substantial vitiation of any one of the five provisions will trigger the prohibition arising from

\footnotetext{
${ }^{19}$ I do not reify a negative. I make no claim here about any particular right, interest or boundary, formed under the banner of some 'magical' public domain, pressing against strong IPR (see E. Samuels, 'The Public Domain in Copyright Law' (1993) 41 Journal of The Copyright Society 137, 150). I merely illustrate the inherent constraints natural rights theories impose on intellectual property rights and the substantial areas of free action vis-à-vis ideas that just-so-happen to result.

${ }^{20}$ See the definition of the public domain Samuelson attributes to Benkler: P. Samuelson, 'Challenges in Mapping the Public Domain' in L. Guibault and P. Hugenholtz (eds), The Future of the Public Domain: Identifying the Commons in Information Law (Alphen aan den Rijn: Kluwer Law International, 2006) 16.

${ }^{21}$ eg it would be foolish to say that certain European countries do not have a robust public domain simply because they have, say, the droit de suite - a right of artists that grants them limited economic rights in future sales of their works - even though this right presses against the 'first-sale' provision noted below.
} 
the forthcoming weight of arguments. ${ }^{22}$ Since the positions of natural rights theorists such as Lysander Spooner and Adam Moore easily achieve this threshold - as do the influential $18^{\text {th }}$ Century views of Diderot, Blackstone and Lord Mansfield ${ }^{23}$ - and since popular discourse routinely assumes that natural rights justify further dissolution of the provisions, we can be assured the following argument is not tilting at windmills.

Second, the following analysis utilises a cluster of terms (fair-use, idea-expression, and the like) that are found within - and sometimes only within - contemporary US intellectual property law. My reason for this terminology is expositional. The US happens to currently utilise terminology for expressing most of the provisions (the ways contemporary intellectual property rights are constrained) that I wish to discuss. But this is not to say these limits are not present in other countries. ${ }^{24}$ Often exactly the reverse is true; in many cases there never arose a need to recognise a specific constraining factor on an intellectual property right

\footnotetext{
${ }^{22}$ One complication: the dissolution of one of these provisions may not trigger the prohibition if there is a radical expansion of all the others. Lord Monboddo's perpetual literary property rights perhaps provides an $18^{\text {th }}$ Century example of such a regime: J. Boswell, The Decision of the Court of Session Upon the Question of
} Literary Property (Edinburgh: James Boswell, 1774) 9-13.

${ }^{23}$ Re Diderot see Boyle, n 1 above, 30-33. The views of Blackstone and Lord Mansfield were more measured than many later absolutist views. Kaplan notes that proponents of perpetual literary property in the $18^{\text {th }}$ Century were aware of the need to narrow the horizontal dimension (as he puts it) of their proffered rights in order to show the tolerability of their perpetuity. B. Kaplan, An Unhurried View of Copyright (New York: Columbia University Press, 1967) 12. Tolerable or not, their positions abnegate the sunset provision without radical expansions to the other provisions and as such do not ensure a robust public domain, as I have defined it.

${ }^{24}$ Often there are clear analogues to these provisions: consider the diverse ways versions of the idea-expression dichotomy arose in the history of British intellectual property: B. Sherman and L. Bently, The Making of Modern Intellectual Property Law (Cambridge: CUP, 1999) 30-35, 66; Deazley (2004), n 2 above, 91, 160-162. Consider also the way the UK has an 'exhaustive list of specially defined exceptions' rather than a general (USstyle) fair use defence: Burrell and Coleman, n 5 above, 249. 
because the right in question was never deemed strong enough to require such constraint. ${ }^{25}$ Ultimately, what matters for my purposes is whether a given regime ensures one way or the other that intellectual property rights are sufficiently attenuated in scope, strength and duration that they allow the public domain to flourish. How this limitation is accomplished in law is not as significant, in the context of this argument, as the limitation itself. ${ }^{26}$

Third, nothing here should be taken to suggest that the provisions as found in contemporary law are exactly right. For instance, as we will see, the commitments of natural rights theories render indispensable a limit on the duration of intellectual property. But this is hardly to say that the US (say) has the limit correctly set - as it is for copyright - as life plus seventy years. It is the shape of the constraint that is important for the purposes of this argument, not its current substance. Indeed, I hope to show natural rights theories have decisive reasons to strengthen the public domain provisions beyond their current compass.

Let us now turn to the provisions themselves. The first two provisions described are limitations on scope - they determine what actually is owned in contemporary intellectual property rights.

The first is that - if we are talking about property rights over $\varphi$ in the familiar sense of the capacity to use $\varphi$ created by the duty of others to exclude themselves from $\varphi$ - ideas are simply never owned. What modern intellectual property regimes allow to be owned in this

\footnotetext{
${ }^{25}$ eg as with the original Statute of Anne, whose protection, read literally, covered only reprintings of the copyrighted book (and hence not even abridgments, adaptations or translations - let alone citations, reviews, parodies and the host of other activities requiring protection through modern fair-use provisions): Burrell and Coleman, n 5 above, 255-256; Deazley (2004), n 2 above, 41, 56, 154, 162.

${ }^{26}$ This is not to say it is insignificant. Whether the law grants tight exemptions or affirms general interests can make a vital difference to the law's flexibility, durability, breadth and predictability: Burrell and Coleman, n 5 above, 249-274; J. Litman, Digital Copyright (New York: Amherst, 2001) 55-58.
} 
familiar sense is a monopoly on certain types of copying and recreating. ${ }^{27}$ It is this monopoly over which an owner may prevent others' interference. The owner has no general right that others exclude themselves from the idea itself. ${ }^{28}$ Allow me to stipulate exclusionary IPR (a proper subset of strong IPR) as the set of rights one would have if one could actually exclude others from the idea itself. Exclusionary IPR only arise in contemporary law - if they arise at all - in official secret documents of the State and in the Law of Confidence; it is here citizens are genuinely prohibited in law from reading, learning and interacting with ideas themselves. ${ }^{29}$ Contrariwise, current intellectual property rights do not require you exclude yourself from knowing about either the abstract structures or detailed minutiae of, say, Tolkien's The Lord of the Rings; you are merely restrained from certain ways of copying that work.

The second limitation on scope occurs in the way intellectual property grants copyingmonopolies over some ideas but not others. When a writer pens a new novel or an inventor crafts a new invention only some of the ideas they create are fit subjects for intellectual property. In copyright precise and specific fictional events, characters and pieces of language are protected - while larger and more general themes, plots, motifs, styles, genres, methodologies, structures and so on are not. In patent only certain types of inventive solutions can be patented; typical conditions require that inventions must be novel, useful and non-obvious. Moreover, the reach of the protection is limited to the patent specifications, and discoveries of fact or general ways of approaching a problem usually are not patentable.

\footnotetext{
${ }^{27}$ Litman, n 26 above, 13; J. Penner, The Idea of Property in Law (Oxford: Clarendon, 1997) 109, 119-120. This provision is not a resolution of the inherent ambiguities of intellectual property - eg when exactly is creating a derivative work copying? It merely fixes the ways those ambiguities are introduced.

${ }^{28}$ This does not mean others have any sort of positive right to demand access to the text. Rather, it simply asserts that if a person happens to be exposed to the text they have no general duty to avoid apprehending it.

${ }^{29}$ Penner, n 27 above, 120.
} 
More broadly, myriad original ideas are entirely unprotected by any intellectual property regimes whatsoever; familiar examples include practical techniques, recipes, dances and fashions. ${ }^{30}$ For expository ease I refer to this set of filters on the possible subjects of intellectual property as the idea-expression provision. This terminological choice is not entirely felicitous. The idea-expression dichotomy is sometimes taken to claim that copyright does not create copying-monopolies over ideas, but only expressions. But in many cases this claim is simply false; copyright in fact provides substantial protection over specific ideas. ${ }^{31}$ For instance, one cannot exactly copy all the scenes, characters, themes and plot of a story even if none of the story's exact sentences or names is used in the copy. Instead, the ideaexpression dichotomy typically operates in law as noted above: as a test of abstraction forbidding general ideas and broad methodologies from falling under copyright's aegis. ${ }^{32}$ The idea-expression provision is thus for our purposes to be understood as referring to the many and diverse restrictions in intellectual property law restraining the types of ideas over which copy-protection will be granted. ${ }^{33}$

The next two provisions are limitations on strength - delineating the power of the intellectual property right. The first such provision is that of fair-use. Fair-use provisions in copyright allow use of a copyrighted work for purposes of education, history, journalism, critique, commentary and satire. Fair-use thus allows non-owners a set of use-specific copying privileges over ideas otherwise copy-monopolised by their creator or her delegates. Similarly themed provisions include exceptions to copyright for purposes of research, private

\footnotetext{
${ }^{30}$ Litman, n 26 above, 104-105.

${ }^{31}$ See N. Netanel 'Locating Copyright within the First Amendment Skein' (2001) 54 SLR 1, 13-20.

${ }^{32}$ See Justice Learned Hand in Nichols v Universal Pictures Corporation, 45 F.2d 119, 121 (2d Cir. 1930) cert. denied, 282 US 902.

${ }^{33}$ Note that the first two public domain provisions are inter-related. The idea-expression provision filters the types of ideas that may subsequently have copying-monopolies granted over them.
} 
study, and archival practices. This type of provision is echoed in patent legislation in the UK and Europe in the form of 'experimental uses'. ${ }^{34}$ This provision allows non-owners, for purposes of research or testing, to utilise an invention or the ideas behind it, notwithstanding the patent-owners' concurrent economic rights. ${ }^{35}$ The result is that one must pay to experiment with an invention, but may not have to pay to experiment on the invention.

The second noteworthy attenuation of creator's rights is the first-sale provision in copyright. This provision allows for first-buyers of books to behave with their purchases as if they were ordinary chattels; in particular they can loan, rent or sell them. The first-sale provision thus allows for the existence of libraries and second-hand book stores. It is for this reason significant in the dissemination of ideas, including those currently held under copyright. Most patented inventions are similarly able to be traded or on-sold as ordinary chattels. Patent also has a separate provision aiding accessibility of the owned idea, for patent applications require a publicly accessible specification of the invention to be lodged at the patent office.

Finally, there is the issue of duration. Copyright, designs and patent all have a mandatory sunset - they operate only for a certain number of years, after which the owner's rights expire. This expropriatory provision nourishes the public domain by ensuring it is constantly fed with a steady stream of new ideas.

To paraphrase the substance of these five provisions: suppose a new idea has been created and publicised - in a book, say. Pro tanto the above provisions mandate you have no general duty to refrain from knowing about everything in it (first provision: ideas-not-owned), no

\footnotetext{
${ }^{34}$ US research exemptions are only for non-profit research institutions. The forthcoming arguments (esp text to nn 74-79 below) imply the justifiability of the UK model.

${ }^{35}$ This analogy between fair use and experimental use defences is drawn by B. Sherman and L. Bently, Intellectual Property Law (Oxford: OUP, 2004) 544.
} 
duty not to copy its abstract themes and methodologies (second provision: idea-expression), no duty not to copy its precise details if you are engaged in a protected activity (third provision: fair-use), no duty not to on-sell or loan out a physical copy of the work you have bought (fourth provision: first-sale), and no duty for you or your descendants to forever forebear from free copying of the entire text (fifth provision: sunsets).

I can now give a more specific account of the target of the forthcoming argument. The five public domain provisions create an environment - a 'robust public domain' - where people are able in many ways to interact freely with the ideas and information surrounding them. I argue in what follows that the machinery of natural rights thinking ensures intellectual property rights must be sufficiently limited as to make room for (at least) this level of freedom. Strong IPR cannot be justified by natural rights.

\section{The prima facie argument and one key weakness}

Consider a prima facie attractive Lockean-esque argument for strong IPR. When it comes to physical property, labouring upon raw resources and incorporating them into my plans often requires (if such projects are to be respected) that others are excluded from such resources. While my labour may not grant me strong rights in the land I work, a less controversial claim is to suggest it at least grants me strong rights to the fruits of that labour - the harvest I reap, if not the land I cultivate. ${ }^{36}$ Now for tangible creations there is a perennial weakness in this 'labour-creation-exclusion' nexus; every tangible creation requires at least some substratum of physical stuff which was not created by me and had to be removed from the commons before being improved by my labour. Notably however, ideational creation does not have this problem. In claiming ownership over my newly created idea (so this argument goes) I claim only that which would not have existed but for my labour, and I leave the commons exactly

\footnotetext{
${ }^{36}$ L. Becker, Property Rights: Philosophic Foundations (London: Routledge, 1977) 34.
} 
as I found it. Thus it is appropriate for me to own this product - and ownership implies exclusionary rights; others cannot use the idea or engage with it in any way, with my consent being regent over these affairs. On this footing it seems reasonable to have exclusionary IPR - permanent powers of exclusion are justified, and the aforenoted five provisions abridging my powers in this regard appear unwarranted.

It seems likely something like the above argument is in the mind of many of those who gesture towards stronger natural author-rights; not only do strong IPR seem justified by the Lockean apparatus, there appears good reason for thinking they are more justified than strong tangible property rights (as these latter must somehow deal with the vexed issue of justifying the removal of something from the commons). ${ }^{37}$

In the next several sections I show a variety of ways this argument must be circumscribed to retain its plausibility, and I show these attenuations require the establishment of the public domain provisions, thus refuting the conclusion asserted above. In the remains of this section however, I wish to expose one deep weakness in the above argument.

The weakness I have in mind is that tangibles-creators can make a stronger case for exclusionary powers over the products of their labour on the basis of non-interference. It is fairly plausible that, for a life-sustaining project to succeed via labour on land, broad powers allowing exclusion of others from that land are required. It is difficult for two persons to labour the same plot of land unless they are engaged in coordinated and mutually accepted

\footnotetext{
${ }^{37}$ See, eg, Spooner, n 13 above, ch I $\$ 6$ [24] (Square brackets indicate paragraph numbers throughout); qv J. Waldron, 'From Authors to Copiers: Individual Rights and Social Values in Intellectual Property' (1993) 68 Chicago-Kent Law Review 841, 879. An interrelated point is the seemingly fuller sense of creation that accompanies idea-creation. See, eg, Hargrave's 1774 argument in M. Rose, 'The Author as Proprietor: Donaldson v Becket and the Genealogy of Modern Authorship' (1988) 23 Representations 71.
} 
projects. $^{38}$ There is thus a commonsense intuition that what justifies granting the farmer exclusionary rights over his product and to some extent his farm is that to fail to do so allows others to interfere with what he is doing - and in this way to harm his legitimate interests. ${ }^{39}$ However, when it comes to ideas the same broadly construed exclusivity is not required to sustain the project and protect the fruits of labour. ${ }^{40}$ If we are interested in protecting people's projects from interference then, 'the scope of the labourer's purpose will help to define the scope of the rights she can assert'. ${ }^{41}$ Suppose we understand the author's project as, for example, the writing and publishing of her book. It is plausible that a prohibition on largescale copying and selling of her book by others is needed to prevent interference in this project, so understood. More hesitantly, we might agree that abridgements and translations of her work also must be regulated. But it is not at all clear another person interferes with our author's project by talking or thinking about her ideas, by using her abstract ideas or broad methodology to create new works, by critiquing, quoting, or reporting on her text, and so forth. These latter activities are, of course, precisely those protected by the public domain provisions. To be sure, delineating what counts as interference in ideational projects is undoubtedly a murkier business than doing so for farming or building. But it must at least be

\footnotetext{
${ }^{38}$ J. Narveson, 'Property Rights: Original Acquisition and Lockean Provisos' (1999) 13 Public Affairs Quarterly 205, 209.

${ }^{39}$ The point is simply that some degree of exclusionary rights is required to protect against interference. But this does not necessarily mandate full property rights. See, eg, M. Peirce, 'Why Libertarians Should Reject Full Private Property Rights' (2001) 32 Philosophical Forum 25; R. Arneson, 'Lockean Self-Ownership: Towards a Demolition' (1991) 39 Political Studies 36, 41.
}

${ }^{40}$ A. Kuflik, 'Moral Foundations of Intellectual Property Rights' in V. Weil and J. Snapper (eds), Owning Scientific and Technical Information (New Brunswick, NJ: Rutgers, 1989) 219, 223.

${ }^{41}$ Gordon, n 12 above, 1548. This is a specific application of a more general precept in natural rights thinking and Lockean theory: 'the justification for a given power is also the justification for the limitations of that power'. Grant, n 11above, 55. 
conceded that one person's use of another's creation, in the realm of ideas, simply is not interference in the straightforward way that it would be in the realm of horticulture. If the reason we are attracted to natural rights thinking is because of its responsiveness to such fundaments as interference and harm, then we immediately have reason to think that the same exclusionary rights over creations granted the farmer are not due the artist or inventor.

\section{The consistency argument}

The most common argument deployed against strong IPR is the consistency argument. This argument does little more than point out that one must be consistent in one's ethical commitments. If others are required to respect the consequences of my $\varphi$-ing, then, ceteris paribus, I am required to respect the consequences of others $\varphi$-ing. The consistency argument points out that I cannot morally demand levels of protection for my ideas that I do not myself recognise for others' ideas. Specifically, I cannot freely build on the publicised ideas of my contemporaries and forebears and at the same time contend others cannot have similar liberties with my publicised ideas. The argument draws attention to the inconsistency evinced in modern intellectual property holders who acquired their ideational resources in one environment, and now seek to sell their own creations under the aegis of a very different regime, without considering the tension involved, or the highly privileged position in which they happen to have located themselves.

Consistency leads the proponent of strong IPR to assert that previous thinkers must have had the same strong rights over their ideas as are being asserted for current thinkers. These previous thinkers' labours may have hitherto been freely plundered, but, as Lysander Spooner declares, they nevertheless, 'have the same true and natural right of property in their discoveries and inventions that they ever had. And they have now the same right to demand the recognition and protection of their rights, that other men have to demand the recognition 
and protection of their rights to their material property'. ${ }^{42}$ But such consistency leads to an array of potential problems for strong IPR.

The problems begin with the fact that our intellectual heritage provides us with the language, concepts, distinctions, knowledge, premises and perhaps even rationality without which the creation of any given new idea is - quite literally - unthinkable. It also provides standards, methods of evaluation, cultural traditions, social mores and aesthetic norms. Faced with the prospect of the prior ownership of this wealth of knowledge and culture, left-leaning natural rights theories emphasise the obvious potential for radical disparities of wealth and power: 'without limitation of term, intellectual property would become an oligarchy dominated by those who got there first' ${ }^{43}$ Right-leaning natural rights theorists instead focus their attention on an individual's capacity for self-ownership and self-governance. They will not countenance an individual beginning her life with sweeping debts to her community owing to the fact that she herself is, one way or another, a product of the community's labour. ${ }^{44}$ If a community could say to a person attaining their maturity, 'you can either choose to eschew some constitutive part of yourself, such as myriad important ideas in your mind, or

\footnotetext{
${ }^{42}$ L Spooner, A Letter to Scientists and Inventors on the Science of Justice, and Their Right of Perpetual Property in Their Discoveries and Inventions (Boston: Cupples, Upham \& Co, 1884) §VI [4].

${ }^{43}$ Mitchell, n 11 above, 7. See also Yen: n 11 above, 556. For historical examples see: M. Rose, 'Nine-Tenths of the Law: The English Copyright Debates and the Rhetoric of the Public Domain' (2003) 66 Law and Contemporary Problems 75, 80-82; J. Boyle, 'The Second Enclosure Movement and the Construction of the Public Domain' (2003) 66 Law and Contemporary Problems 33, 54-56.

${ }^{44}$ Contrary to Moore (n 13 above, 170-171) there is no need to appeal to society as a whole for this argument to gain traction. It works just as well referring to past individuals who created the ideas, and those individuals whose projects are to sustain or communicate them.
} 
else consent to our demands for payment', this would deeply undermine any possibility of self-ownership. In general, libertarians are aware of the need to avoid this result. ${ }^{45}$

It is tempting at this point in the argument to offer startling examples of ancient ideas that, at least according to perpetual and exclusive IPR, should apparently be owned by their creator or his heirs. Imagine if basic ideas for mathematics, logic, story-telling, husbandry, tool-making, subject-predicate sentences and so on were forevermore annexed by the first human who managed to understand and articulate them. However, making such a fanciful list can distract us from the wider application of this argument. Many ideas - not merely those very first realisations by ancient creators, but also the works and innovations of the last several generations - come to serve as bedrock platforms for entire realms of subsequent creative activity. The historical application of the consistency argument forces us to consider how future citizens will appraise our intellectual property regimes. Their ethical concerns are likely to mirror what we think now about the absurdity and unreasonableness of demanding payment for quotations of Martin Luther King or J. F. Kennedy, for replication of the basic rhythms of rock and roll or hip-hop, for derivations and adaptations from Isaac Asimov or J. R. R. Tolkien, for responses to John Rawls's arguments and Alfred Kinsey's data, for use of the technological and industrial possibilities created by Alan Turing and Henry Ford, and so on indefinitely. The public domain provisions have ensured our generation was not born into a world where we had to pay for the use of the ideas saturating our environments, forming our cultures, and constituting irremovable aspects of our mental lives.

Various arguments have been offered by strong IPR advocates in an attempt to deflect these barbs offered by the historical application of the consistency argument. It has been suggested, for instance, that perhaps we fully paid for our currently-held ideas when we paid

\footnotetext{
${ }^{45}$ See, eg, R. Nozick, Anarchy, State, and Utopia (Oxford: Basil Blackwell, 1974) 95, qv 38-39; A. Rand, 'Patents and Copyright' in Capitalism: The Unknown Ideal (New York: New American Library, 1967) 131.
} 
for our education. ${ }^{46}$ This argument fails. It does not justify the educators having themselves any rights to the ideas they teach. Nor does it deal with myriad other social and interpersonal sources of education, inspiration and information.

An alternative tack is to speculate that perhaps we do not owe compensation to historical creators because all currently available information and ideas have been 'given' or 'freely shared'. ${ }^{47}$ But unless we have specific evidence that the creator has waived their rights to all recompense or control over the product of their labour, then the default moral position must be that such rights are still vested and therefore that strings are attached. ${ }^{48}$ After all, the precept that placing ideas into a public milieu may be considered evidence of releasing one's title over them would be, if true, a straightforward argument against all copyright and patent. It is hardly available to the strong IPR advocate to make any such contention.

A more promising counter-argument might begin by asserting that an independent creator of an already-owned-idea is to be vested with the same set of rights as the first creator. ${ }^{49} \mathrm{~A}$

\footnotetext{
${ }^{46}$ Moore, n 13 above, 172-173.

${ }^{47}$ Inexplicably, both Moore (ibid 171-173) and Nozick (n 45 above, 95) use these phrases to refer to publicly available ideas, apparently unaware of the clear tension invited given their positions on copyright and patent (where public revelation nowise suggests 'free sharing'). Nozick's position on patent is given at: ibid 181-182. ${ }^{48}$ As Nozick puts the operative principle: 'If doing act A would violate Q's rights unless condition C obtained, then someone who does not know that C obtains may not do A' (ibid 106). Spooner contends we must judge the probability of gratuity on the basis of the market value of the idea. Ceteris paribus, a person is less likely to gift something of great value: $\mathrm{n} 13$ above, ch II §2 [14]-[17]; see also Spooner’s discussion of de minimis, ibid ch IV [69]. This plausible solution hardly helps the matter at hand however, for it is precisely the most valuable ideas that are creating these sweeping debts to our forebears. Spooner thus fares no better than Nozick or Moore on this matter. He avoids catastrophe only by eschewing his solution at the salient moment and simply asserting that 'the dead have no right of property in either the intellectual or material things they have left to the living': ibid ch II $\S 5$ [8].

${ }^{49}$ Moore, n 13 above, 166; Spooner n 13 above, ch II, §7 [2].
} 
person is not allowed to free-ride on my labour by helping themselves to my creation, so this thought goes, but if they independently labour to come up with the same idea, then naturally they acquire the same rights over it. This is an eminently reasonable inclusion to make, independently justified by the original labour-respecting fundaments. At first blush, it can seem as if this move might deflect at least the most catastrophic consequences of the consistency argument by allowing another Ford or Turing to break the former's intellectual monopoly. But this move carries its own problems.

First, immense logistical difficulties arise when it comes to dispute resolution. How is it possible to tell whether an invention was independently created or not? Whether putative independent inventors are routinely believed or disbelieved, the possibilities for the systematic marginalisation of rights-claims at this point seem very difficult to avoid. ${ }^{50}$

Second, as advocates of strong IPR, both Moore and Spooner allow the publicising of a new idea - while retaining proprietary strings over it, of course. Such publicising effectively pre-empts the possibility of independent invention. That is, I can publicise my new idea in such a way that I make you know about it. It is then not possible for you to independently create it, and so impossible for you to ever challenge my monopoly. Whether or not this result is morally acceptable in itself will be discussed in the next section; the immediate problem is that the publicising of foundational ideas removes the opportunity for others to arrive at them independently. Again, the spectre of ownership of bedrock ideas arises.

With the failure of these several rejoinders to the historical application of the consistency argument, it becomes hard to see how breathtaking inequalities in inherited intellectual capital - and the ensuing possibilities for exploitation - could be avoided. It is also not clear how the education and self-education of the new generation could occur without the

\footnotetext{
${ }^{50}$ H. Breakey, 'Liberalism and Intellectual Property Rights (2009) 8 Politics, Philosophy and Economics 329, $340-342$.
} 
unilateral imposition of substantial duties of recompense - threatening that generation's subsequent capacity for self-ownership and self-governance.

There are further problems for strong IPR posed by the consistency argument. As time progresses and ideas are built upon one another the legal complexities invited by strong IPR begin to look prohibitive. Many ideas will be accessible to people, but strings-upon-strings will be attached to these ideas (as already occurs in Reach-Through-License-Agreements in patent law ${ }^{51}$ ). New creators will only be entitled to their profits when they have paid off everyone (at least of the last generation or two - presuming non-perpetual IPR) upon whose intellectual shoulders they have stood. The level of stultifying bureaucratisation and labyrinthine legalese already created by current intellectual property regimes is welldocumented. It was recently charged that modern patent's treatment of biomedical breakthroughs effectively constitutes an 'anticommons'. ${ }^{52}$ An anticommons (so the theory goes) arises when so many exclusionary rights are held by so many different agents over some one thing, or the necessary ingredients of some one thing, that the transaction costs of negotiating use of that thing become prohibitive. ${ }^{53}$ While such claims are still fairly speculative ${ }^{54}$ the level of bureaucracy created by extant copyright in music and cable television is dismayingly real, ${ }^{55}$ as are the levels of documentation required by libraries in

\footnotetext{
${ }^{51}$ M. Heller and R. Eisenberg, 'Can Patents Deter Innovation? The Anticommons in Biomedical Research' (1998) 280 Science New Series 698, 699.

52 ibid.

${ }^{53}$ M. Heller, 'The Tragedy of the Anticommons: Property in the Transition from Marx to Markets' (1998) 111 HLR 621, 622.

${ }^{54}$ R. Epstein and B. Kuhlik, 'Is There a Biomedical Anticommons?' (2004) 27 Regulation 54.

55 T. Streeter, 'Broadcast Copyright and the Bureaucratization of Property' (1991-92) 10 Cardozo Arts and Entertainment Law Journal 567, 575-581.
} 
order to show their conformity to various aspects of copyright law. ${ }^{56}$ Enlarging the scope, strength and duration of intellectual property threatens to exponentially increase the difficulties at every level - upon the creation of a new idea, at point of sale, and when the need for dispute-resolution inevitably arises. Now it may be, of course, that all these mushrooming bureaucracies, international negotiations, police-powers, economic-costs and personal record-keeping requirements are the price we have to pay for natural justice - and such is the gist of Spooner's rejoinder to this concern. ${ }^{57}$ But other natural rights thinkers may not be quite so unconcerned when it comes to the stultifying social, economic and personal costs of such bureaucratisation.

Additionally, the flow and progression of science, technology, culture and learning has until now occurred because of people's liberties to copy, learn, critique, refute, synthesise, subtilise and generally bounce off others' ideas. This largely free interchange of ideas and information has resulted in great progress in many forms of learning and may even be an important mechanism for the evolutionary distillation of truth and our consequent surety in such knowledge as we possess. ${ }^{58}$ Strong IPR, requiring some level of payment and consent for many of the ideas we might use in creating new innovations, will severely restrict what we have come to understand as the natural progression of science and learning. ${ }^{59}$ While a modern reader might suppose a commitment to intellectual progress to be a purely utilitarian

\footnotetext{
${ }^{56}$ Burrell and Coleman, n 5 above, 147-149.

${ }^{57}$ Spooner, n 13 above, ch II $§ 10$ [3]-[4].

${ }^{58}$ J. Mill, On Liberty (Cambridge: Hackett, 2003) ch 2. The consequences for evolutionary epistemology were likely a significant factor in F. Hayek's rejection of intellectual property. See Cahir, n 11 above, 9.

${ }^{59}$ This concern dates at least back to Locke himself. In a 1694 Memorandum he pronounced the current patents on printing ancient authors as 'very unreasonable and injurious to learning'. L King, The Life of John Locke:
} With Extracts from His Correspondence, Journals and Commonplace Books (London: Henry Colburn and Richard Bentley, 1830) 386, qv 379-380. 
goal, largely peripheral to considerations of natural justice, it would not have been characterised thus by many natural rights thinkers themselves. In the high-water mark of natural rights thinking in the $18^{\text {th }}$ Century, the orthodox view was very much that progress towards human enlightenment was inescapably interwoven with human freedom - that 'the liberation of the mind and the liberation of the citizen were complimentary processes ${ }^{60}$ And these views on progress and access to knowledge were straightforwardly applied to the question of literary property rights. ${ }^{61}$

One response to these concerns is to contend that these worrying consequences are overplayed: arguing that in this case at least, fiat justitia need not ruat coelum. To this end Moore stresses that merely because authors and inventors can exercise these powers is no indication that they will - especially because we should expect market pressures to force them to do otherwise. ${ }^{62}$ A book one cannot sell, loan or read aloud is worth less than a book without these legal fetters. So too is a book where one must pay for each additional reading. So too is a book where one is constrained in one's capacity to talk about, think about, and creatively use the book's ideas. If so, then authors vying for market position will cede as many of these claims as they can in order to make their product more inviting. In this way it may be that the flow of knowledge and intellectual progress are not constrained in as dire a manner as suggested above.

\footnotetext{
${ }^{60}$ D. Williams, Condorcet and Modernity (Cambridge: CUP, 2004) 101. The influence of Locke was significant in this respect: see K. Martin, French Liberal Thought in the Eighteenth Century (London: Phoenix House, 3rd ed, 1962) 13, 122.

${ }^{61}$ eg Condorcet, n 11 above, 58.

${ }^{62}$ Moore, n 13 above, 159-162; Cahir, n 11 above, 22.
} 
It is a subtle question how far Moore's appeal to the market will take us in mitigating the consequences for science and learning arising from strong IPR. ${ }^{63}$ One serious problem with the argument is that it evidently will not apply to ideas whose creator has more refined priorities than making money - so newly minted religious ideas or political arguments would be effectively insulated from critique and warning. ${ }^{64}$ Indeed, entire artistic genres might be prohibited from deviating in sacrilegious directions. ${ }^{65}$

But in the end, perhaps, this bullet can simply be bitten. While some natural rights perspectives are internally committed to the growth and dissemination of learning and culture, many others are not. The strong IPR advocate can simply accept that instantiation of their favoured regime may indeed have invidious consequences for the progression of learning and social epistemology's capacity to track the truth. However - they might continue - we cannot ignore the claims of rights merely because we are worried about unfortunate consequences to progress and knowledge. The lesson of Faust is apposite here.

In all, we are still some considerable distance from establishing a necessary relation between natural rights and the public domain. Perhaps the only place where the consistency argument proves decisive is as regards the fifth provision of sunsets. For it is when intellectual property rights are perpetual that the consistency argument is able to derive genuinely absurd conclusions regarding the ownership of bedrock ideas and the imposition of

\footnotetext{
${ }^{63}$ Against Moore's position, Yochai Benkler argues the high transactions costs involved in end-users renegotiating mass-market form contracts give the information vendor a particularly powerful position. Y. Benkler, 'Free as the Air to Common Use: First Amendment Constraints on Enclosure of the Public Domain' (1999) 74 NYU Law Review 354, 434.

${ }^{64}$ Even with the five provisions largely in place, history bears witness to the application of copyright protection to political argument and religious texts. See Netanel, n 31 above, 7.

${ }^{65}$ Boyle notes the veto-power strong copyright could have granted to gospel songwriters over the birth of soul music - a veto they might well have utilised on the basis of sacrilege: $\mathrm{n} 1$ above, 134-136.
} 
astronomically complex duties to pay off all our intellectual forebears. But if a regime of strong IPR at least includes sunset provisions, then the consistency argument's conclusions become more limited. Worries about exploitative inequalities created by inherited capital will be sufficient, in all likelihood, for leftist natural rights theorists to reject strong IPR. But more right-leaning theorists may be willing to bite the bullets of increased bureaucratisation and the potential chilling of science, culture and learning, and may adopt a more modern libertarian conception of self-ownership. Such a conception may be largely silent on issues (such as education) arising prior to an individual attaining their majority. Thus far, while I hope some ground has been gained, strong IPR from natural rights is a live possibility.

\section{Robust universalisability}

In the last section we saw the strong IPR advocate must be drawn into consistently applying the same moral rule to themselves as they apply to others. However, many natural rights theories go beyond this mere consistency requirement to a more robust understanding of universalisability. Before articulating what this move might amount to, and explaining the reasons why it is often made, I must emphasize that not all natural rights theories are committed to robust universalisability in all instances. Indeed, it is typically this very commitment that marks the distinction between libertarianism and left-libertarianism, and effectively divides two traditions of Lockean scholarship. ${ }^{66}$ The libertarian has theoretical and practical reasons pressing against their accepting this type of universalisability in at least some important applications. In the following section I show how these commitments of the libertarian clearly rule out strong IPR. In this section, I argue that the type of robust

\footnotetext{
${ }^{66}$ The divide surrounds how robustly the Lockean proviso is understood. A robust reading is given by, eg A. Simmons, The Lockean Theory of Rights (Princeton: Princeton University, 1992) 282-306. An ultimately vestigial reading is given by C. Macpherson, The Political Theory of Possessive Individualism: Hobbes to Locke (London: OUP, 1964) ch 5.
} 
universalisability prized by the left-libertarian and the (non-libertarian) Lockean also prohibit strong IPR.

Robust universalisability mandates that, 'if I ask for respect for the consequences of my $\varphi$ 'ing, it is only reasonable that I do not (by my $\varphi^{\prime}$ 'ing) undermine others' opportunities to $\varphi ’{ }^{67}$ Robust universalisability might be motivated by a Kantian rationality, where concerns for fairness rule out a moral law privileging persons who simply arrived first. ${ }^{68}$ Alternatively, it might be justified by entitlement's focus on interference, and morally accepting that our actions (including our appropriations) cannot worsen the situation of others in key ways - in particular we cannot systematically undermine their opportunities to do what we are now doing. ${ }^{69}$ Finally, the point of respecting the consequences of some action may be derived from some deeper core right of all persons - and hence it would be counter-productive to allow some people's exploitation of the right to undermine the opportunities for others to undertake those same activities. ${ }^{70}$ This is the case, arguably, in Locke, where respect for labour is motivated by its importance in facilitating economic independence. This independence is in turn required to respect everyone's fundamental interest in self-

\footnotetext{
${ }^{67}$ The failure of any given right to be robustly universalisable is a serious impediment to its justifiability. See H. Breakey, 'Without Consent: Principles of Justified Acquisition and Duty-Imposing Powers' (Forthcoming. DOI: 10.1111/j.1467-9213.2008.571.x.) The Philosophical Quarterly §IV.1.

${ }^{68}$ H. Steiner, 'Justice and Entitlement' (1977) 87 Ethics 150, 151; I. Kant, Lectures on Ethics (Cambridge: CUP, 1996) 337.

${ }^{69}$ Applying the proviso on this construal to intellectual property rights see, eg, Gordon, n 12 above, 1563; Moore, n 13 above, 87-88. Moore's applied interpretation of non-worsening does, I argue below, in fact seriously diminish others' opportunities for invention and creation. Moore himself admits some ambivalence towards this possibility, though his final position appears to settle against sunsets for non-discovery ideas: ibid 166-167.

${ }^{70}$ On derivative and core rights, see J. Raz, The Morality of Freedom (Oxford: Clarendon, 1986) 168-170.
} 
governance. ${ }^{71}$ If any of these several concerns are warranted, then any rule not universalisable in this robust, opportunity-preserving sense will fail to protect the fundamental right in all persons.

Any attempt to have intellectual property appropriation fill this condition leads to two separate and important concerns. The first problem is that publicising, selling, advertising or sometimes just using any newly-created-invention can show everyone the ideas behind it. This occurrence, as noted in the previous section, then pre-empts anyone else's independent creation of the idea. Prior to exposure, the person had an opportunity to independently come up with the idea. Once exposed to the idea, the person no longer has any such opportunity. This is a clear failure of robust universalisability - the rights I have secured over the idea, and my subsequent exploitation of those rights, prevent you having the opportunity to similarly come up with the idea. How can this worsening be justified?

Two possible lines of defence are offered by Moore to suggest these pre-empted independent creators are not worsened. First, Moore argues there is yet an infinite array of other ideas later inventors could come up with. ${ }^{72}$ If this were so, and these ideas were relevantly similar in terms of accessibility and importance, then complaining about preemption would be equivalent to a person on an infinitely large rocky beach objecting to another's appropriating one particular and unremarkable rock for themselves. But this argument rests on an implausible understanding of the nature of ideas, their creation and interrelation. There is quite possibly an infinite amount of useful, beautiful and true ideas out there to be grasped, but only insofar as we can continuously build on what has gone before. If

\footnotetext{
${ }^{71}$ This interpretation is emphasised in Simmons, $\mathrm{n} 66$ above, 85, 274. Understanding rights as protecting key interests is given its modern articulation in Raz, $\mathrm{n} 70$ above, ch 7 . When it comes to tangible resources, the Lockean proviso - leaving enough and as good for others - is plainly an attempt to fulfil this type of robust universalisability (though see n 66 above).

${ }^{72}$ Moore, n 13 above, 127.
} 
we cannot build upon the prior creations, techniques, methodologies and realisations of science, philosophy, technology and culture, and we are proscribed from re-inventing such basics as the wheel, lever, switches, cranks, tonic-dominant-major-third musical progressions, three-act plot structures, and perspective in visual art (because they have already been created and publicised) then it is not at all clear equivalent labouring is remotely likely to come up with equivalently useful, beautiful or true ideas. ${ }^{73}$ Indeed, if Moore's theory about ideas were true it is a wonder anyone would ever bother with education at all, seeing as any inventive person could putatively reach out and pluck entirely new useful and beautiful ideas from the infinite plane where such ideas reside.

Moore's second response is to point out that the losses incurred by the late-comer are, largely, market losses. As Moore observes, this presumes a market to be in place - and hence presumes property rights are assigned over ideas. ${ }^{74} \mathrm{We}$ can hardly complain about the losses we incur by an earlier appropriation when the calculation of those losses itself presupposes an undergirding system of appropriation. Moore's reply certainly seems cogent if it is put to a person who has been worsened because, for instance, he was planning to grow potatoes and another earlier person has already started doing so, thus driving down the market-value of this later persons' planned horticultural venture. The reason for this cogency is twofold. First, the initial act did not actually prevent the later act from occurring, but only altered the profitability of its consequences. Second, these sorts of market losses are an inevitable part of a regime of alienable property, and hence the complainer is in a sense at once requiring and decrying the existence of the basic system.

But Moore's response seems in just these two ways to be misplaced as applied to the preemptive publicising of a new idea. First, the initial inventor straightforwardly does prevent

\footnotetext{
${ }^{73}$ For further arguments and examples see Gordon, n 12 above, 1556.

${ }^{74}$ Moore, n 13 above, 164.
} 
others from engaging in the same act. Once someone has told you the solution to the riddle, you cannot independently work it out for yourself. Second, this result is not an inevitable part of a market in ideas, as the five public domain provisions allow for exactly such opportunities to be preserved. Sunset clauses and research exemptions, for example, allow later inventors to be able to work upon the new idea. Though they can no longer invent this particular idea, ${ }^{75}$ they can use it as a foundational premise, general resource or touchstone to invent some further new idea. In a similar way, the ideas-not-owned and fair-use provisions allow intellectual labourers to create new ideas from old ideas - in this case not using the idea as a foundation, but rather using it as evidence, data, artistic device or comic inspiration in some other ideational project.

This perhaps is the sense that can be made of Moore's intimations that prospective inventors are better off in a regime with sunsets - and, I add what he does not, with research exemptions, fair-use and the raft of other provisions. ${ }^{76}$ While it is exiguous compensation for a person who would have invented idea $\varphi$ for $\varphi$ to be distributed to all, on an institutional level the type of person who would have invented $\varphi$, that is, a creative, ingenious inventor, is bettered by the regime which, $\varphi$ having been invented, provides her with $\varphi$ as accessible inspiration or premise for further ideas.

To sum up this first problem for strong IPR: the conjunction of 'prohibiting commercial copying except by independent inventors' and 'allowing owners to pre-empt independent invention by public advertisement' breaches robust universalisability by allowing current idea-creators to behave in ways preventing future persons from behaving similarly. Enforcing

\footnotetext{
75 They may well be worsened if they have already spent significant labour on a project, when another creator beats them to exactly the idea they were aiming at. It is difficult to envisage workable protections assuaging this sort of worsening, and hence it might be justified as analogous to the above potato-farming case.

${ }^{76}$ Moore, n 13 above, 166-167; similarly Nozick, n 45 above, 181-182.
} 
provisions such as ideas-not-owned, fair-use, research exemptions and sunsets allows robust universalisability by ensuring ideas-creators always have the opportunity to freely create from the publicly apprehensible ideas and information around them.

The second problem created by robust universalisability is that the opportunity to reinvent some fairly well-known idea is not as substantial as the opportunity to genuinely be the first to uncover an idea - to act on the cutting edge of knowledge, technology or art. There are manifest reasons why it is not the same opportunity economically. As with all market goods, the more supply there is of a product, the less the price that can be attained for it. But this first consideration is exacerbated by a second feature of ideas - the marginal cost of producing extra tokens of the invented type (eg extra books from the first pressing, more inventions from the same blueprints) can often be very small compared to the research costs of creating that first idea. Boyle evocatively describes the limit case: 'the result of a $\$ 100$ million genetic research project could be stored on a 50-cent diskette, and then copied at 50 cents a time...,77 This capacity to cheaply flood the market means the asking price in a duopoly may be very much lower than the price demanded in a monopoly. If so, then later inventors of the same idea can expect substantially smaller returns than first inventors. Since the opportunity to reinvent is not as economically significant as the opportunity to invent, the opportunity is not equivalent in the sense of allowing a person to materially sustain themselves through the activity (and hence has different ethico-political status if we are interested in, for example, the natural rights concern for economic independence). Nor is the opportunity to reinvent old ideas similar to the opportunity to create something genuinely original in terms of personal achievement, public interest, contribution to society, or peer admiration. If this differential outcome was an inevitable part of any ideational-labour-respecting regime, then there might

\footnotetext{
${ }^{77}$ J. Boyle, Shamans, Software, and Spleens: Law and the Construction of the Information Society (Cambridge, Mass: HUP, 1996) 8.
} 
be little to be done about it. However, as we saw above, if the invented idea is granted as a premise, data or inspiration able to serve as a platform for others' creations, then the opportunity to invent (and not just reinvent) can be sustained over time. ${ }^{78}$ Thus, the genuinely valuable opportunity to come up with something truly new can be protected through the use of the five provisions. ${ }^{79}$ Strong IPR, removing one or more of the key provisions, fails to preserve this opportunity and subsequently fails the condition of robust universalisability.

\section{Libertarianism and strong IPR}

To sum up so far: I argued sweeping exclusionary powers over ideas are poorly justified by concerns for noninterference. I sketched several serious consequences arising from the consistent application of strong IPR. I argued that concerns for fairness and equality (manifested in a robust opportunity-preserving universalisability) rule out strong IPR.

Nevertheless, a dogged interlocutor could still maintain there may be some natural rights theory that overcomes the hurdles regarding non-interference, bites the several bullets of the consistency argument, and is unmoved by concerns with robust universalisability. As highlighted earlier, in at least some important contexts libertarian theorists do not accept robust universalisability - namely, in application to appropriation of landed property. But it would be too swift to characterise libertarians as entirely insensitive to the attractions of

\footnotetext{
${ }^{78}$ This point may be made in terms of inter-generational equity. See Gordon, n 12 above, 1557-1558; Hughes, n 8 above, 204.

${ }^{79}$ Note the second argument of this section differs from the first argument inasmuch as the problems of the first were entirely caused by public advertisement. In cases where the idea never became publicly apprehensible, this first application of robust universalisability is not breached because others are still free to independently produce the idea in question. However, even in such cases robust universalisability might still be breached in the manner presented in this second argument. That is, later persons would only be offered the opportunity to re-invent, which is in key ways not as substantial as the opportunity to invent.
} 
robust universalisability. Indeed, the libertarian rejection of robust universalisability as applied to land (ie the libertarian rejection of the strong Lockean proviso) is usually prefaced by arguments contending that robust universalisability is simply unworkable in that application. ${ }^{80}$ It is thus not implausible to expect that when faced with the prospect of rights that are robustly universalisable (as the previous section held was the case for intellectual property rights shaped by the public domain provisions) many libertarians would immediately accept such a regime. ${ }^{81}$ Many - but perhaps not all. Some libertarians more or less explicitly deny the need for any such restriction on property acquisition. ${ }^{82}$ It is directly to this remaining subset that the several arguments of this section are targeted.

In this final section therefore, I seek to close the trap by showing why libertarians in particular cannot afford to be cavalier in their choice of norms respecting ideational labour. As I address myself primarily to the libertarian, in this section I construe the shape and substance of rights such as private property and self-ownership in strong terms. But it is worth bearing in mind that such rights have an important role in most natural rights systems and hence serve as additional reasons for securing a robust public domain. A standard reading of Locke or Hegel, or of most contemporary left-libertarians, would find them committed to

\footnotetext{
${ }^{80}$ See text to $\mathrm{n} 91$ below.

${ }^{81}$ Ayn Rand is perhaps a good example. Rand's intellectual (but not her tangible) property rights are robustly universalisable: n 45 above, 131-133.

${ }^{82}$ These theorists do not counter robust universalisability directly, but rather argue Lockean provisos rest upon an assumption of initial common ownership. Narveson, n 38 above, 212-213; E. Feser, 'There Is No Such Thing as an Unjust Initial Acquisition’ (2005) 22 Social Philosophy and Policy 56, 58-64.
} 
self-ownership, private property and robust universalisability. ${ }^{83}$ The rejection of strong IPR in such regimes will thus be over-determined by their first principles.

We have already encountered in passing some reasons why the libertarian may be disinclined to accept strong IPR. The archetypal libertarian is fundamentally concerned with non-interference and is likely to, as Mill expressed the disposition, 'prefer to bear almost any amount of social evil rather than add one to the departments of human interests amenable to governmental control' ${ }^{84}$ Hence several of the concerns adduced earlier explain why many libertarians are wary of strong IPR.$^{85}$ But such concerns are more suggestive than definitive, and in any case the libertarian might be expected to evince considerable sympathy with the entrepreneurial spirit of the labour-respecting argument with which we began. If so, such sympathy should be short-lived. When it comes to assertions of welfare rights the libertarian response has been to immediately shift their gaze from the apparent attractiveness of such

\footnotetext{
${ }^{83}$ All three commitments are present in Locke's famous chapter on property, n 4 above, Bk II, ch 5. Re Hegel see $\mathrm{n} 17$ above. Re left-libertarianism, a useful anthology is H. Steiner and P. Vallentyne (eds), Left-

Libertarianism and Its Critics (Basingstoke: Palgrave, 2000).

${ }^{84} \mathrm{n} 58$ above, 8. Non-interference was discussed at text from n 38 above. Bureaucratisation was discussed at text to nn 51-57 above.

${ }^{85}$ It is revealing that Nozick (n 45 above, 141) suggests different libertarians, and different rights-enforcement agencies, can reasonably disagree about the extent of intellectual property rights. He notes Rothbard and Rand as examples of the spectrum. Yet Rand - who sits at what Nozick calls the 'full-blooded copyright' end of the spectrum - is not a proponent of strong IPR. She offers straightforward libertarian arguments from her fundaments of productive independence and freedom of mind against strong IPR. See Rand, n 45 above, 131133; A. Rand, 'The Objectivist Ethics' in The Virtue of Selfishness: A New Concept of Egoism (New York: New American Library, 1964) 23. The several arguments of this final section contend that Nozick was, by perhaps happy accident, accurately delineating the scope of viable libertarian positions, with the strongest coherent libertarian intellectual property rights regime - as with Rand - explicitly mandating space for a robust public domain.
} 
rights to the duties imposed by those rights - and to consider whether such duty-impositions are consistent with the prior rights of the person subjected to them. As we will see, the libertarian would do well to pay the same searching attention to the duty-impositions created by strong IPR.

Three indisputable commitments of the natural-rights libertarian are that they are in favor of free markets, private property rights (ie property rights in tangibles such as land and chattels) and self-ownership. The libertarian's position on freedom of speech, appearing in one of two forms, provides additional leverage.

I begin with the free market. In general, natural rights advocates of the free market will have immediate concerns arising from the nature of intellectual property's state-sanctioned monopolies. Such monopolies may be viewed as nothing more than government interference in basic economic freedoms. ${ }^{86}$ But even natural rights libertarians who do not take this view still have cause for concern. The free market requires that market agents can respond strategically to their competitor's new products, strategies, business methods and the like. Ordinary market agents allow all manner of information and ideas to be drawn from their novel products or practices, they allow their discussion and critique, and they allow myriad

\footnotetext{
${ }^{86}$ As with Rothbard and Hayek. See the treatment of patent in M. Rothbard, Man, Economy and State with Power and Market: Government and the Economy (Auburn, Alabama: Ludwig von Mises Institute, 2004) 745753. (Rothbard's positive appraisal of copyright is premised on his (early) view that a limited copyright regime may be created from no more than tangible property and contract: ibid.) It is a subtle question whether F. Hayek is a natural-rights libertarian (emphasising his Kantian and Humean roots) or a very indirect utilitarian (See J. Gray, Hayek: On Liberty (London: Routledge, 3rd ed, 1998) 58-60). If we interpret Hayek as a natural rights thinker, then his commitments to the free-market and private property will be decisive in rejecting intellectual property. If we understand him as an indirect utilitarian, then the rejection of strong IPR will be primarily accomplished by his social epistemology (see Cahir, n 4 above, 9).
} 
derivative, competitive and complementary ideas to occur to enterprising persons without reimbursement needing to be paid.

The free market thus requires the first two public domain provisions. The first provision (ideas-not-owned) allows the use of an idea for the crafting of responses to it, and the second provision (idea-expression) mandates that many novel ideas are not fit subjects for intellectual property. In combination, these provisions ensure that companies cannot prevent market responses to their newly developed ideas, and that most such ideas have no copying monopolies over them. To take just one example, without the first two provisions companies could potentially appropriate their original and laboriously created ideas concerning new market niches. ${ }^{87}$ To allow such ideas to be appropriated by strong IPR would threaten to return the libertarian's prized free market to the system of guild monopolies it once eclipsed.

Furthermore, it is common practice for market agents and buyers to discuss, record, warn about, reconceptualise, compare and critique new products and market strategies. But when the new product is itself understood as an idea, all these activities can now be described as ways of copying the product (or at least those parts of the product necessary to penning a précis, critique, market report, and so on). Such ordinary market activities can thus breach an owner's monopoly on copying. Much of the core of the third-provision - of fair-use copying for privileged uses - allows these normal market activities to be performed even over the subjects of intellectual property. That is, copying the idea for the purpose of communication, discussion, analysis and critique are privileged. Provisions such as fair-use thus do not involve placing an extra demand on ideational labourers above that required of tangible

\footnotetext{
${ }^{87}$ See, eg, the discussion of Sony's Walkman in N. Rosenberg, Exploring the Black Box: Technology, Economics, and History (New York: CUP, 1994) 5.
} 
labourers. ${ }^{88}$ Quite the contrary. Idea-creators lobbying for strong IPR are in the business of grasping controls over their created ideas that inventors of new market strategies do not claim - and could not possibly claim without radical overhaul of the market.

The two remaining provisions also gain support from a commitment to the free market. The first-sale provision allows the trading and sharing of objects with intellectual property subsisting in them as if they were normal chattels, subject to normal market forces.

Dissolution of this provision, especially in combination with weakening the sunset provision, potentially encumbers indefinitely many physical objects with conditions over their sale and loan. In so doing it invites mushrooming anti-commons, bureaucratisation, record-keeping and enforcement costs. In sum, the commitment to the free-market gives the libertarian compelling reasons to accept the first three public domain provisions and substantial reasons for inclining towards the last two.

The second baseline commitment of the libertarian is their commitment to private property. Strong IPR cause fundamental problems with, on the one hand, the justifications that can be given for private property, and, on the other hand, for the substance and strength of those rights.

In regard to the issue of justification, regimes of strong IPR do not leave prior ethical arguments for private property as they were. Private property justifications in the natural rights traditions legitimise private property in two ways: either by lauding certain actions that may be taken on one's own on the property, or by showing that the property-appropriation does not leave others worse off. Intellectual property rights cause serious problems with both modes of justification.

\footnotetext{
${ }^{88}$ As suggested by B. Lehman (Chair) US Working Group on Intellectual Property Rights, White Paper: Intellectual Property and the National Information Infrastructure (1995) 96.
} 
We begin with the former. Consider just a handful of the myriad justifications offered for natural private property rights throughout history: private property provides a domain where one can, on one's own and without the say-so of any other person, achieve economic independence and the accompanying control of one's life and happiness, creatively exert one's will and so cultivate one's personality, reap the natural consequences of one's actions and inactions, freely choose and develop one's own experiment in living, find a haven to thoughtfully assimilate the multiplicity of the public domain, or develop one's personal and social virtues by productive work, prudence and voluntary charity. Almost all these intentional uses of land and chattels are predicated on a substrate of knowledge, skills, concepts, tools, methodologies, techniques, language and know-how. To the extent intellectual property allows other people to control the uses (and perhaps even the general availability) of all those requisite ideas and information pro tanto they undermine these lines of justification. For now it turns out that perhaps private property is not, after all, a place where these laudable activities can be undertaken without the say-so of others - as those others might control various parts of the intellectual requisites of those activities. Even weak intellectual property rights are not without problems on this footing; they will require that many of the above activities cannot take place with the entirely unfettered regency of choice ordinarily ascribed by most justificatory arguments to the private-property-owner. Strong IPR create increasingly substantial duties - duties constraining not merely the commercial uses of private property but increasingly intruding into the most private sphere of the individual. The German Supreme Court was explicit on this point: 'there is no general principle in copyright law that maintains that the claims of the copyright holder should stop short of the private sphere of the individual. ${ }^{, 89}$ Indeed, some intellectual property intrusions into home and hearth are substantial enough they may be critiqued by means of the right to privacy as much as the

\footnotetext{
${ }^{89}$ Quoted in L. Guibault, Copyright Limitations and Contracts (London: Kluwer Law International, 2002) 50.
} 
right to private property. ${ }^{90}$ Ultimately, as more and more of the above-noted activities become dependant upon successful negotiation with others, strong IPR increasingly undermine the very reasons the natural rights theorist had for granting private property in the first place.

Justifications of private property are also made by showing appropriations of property do not worsen the position of others. There is an abiding problem with applying this sort of nonworsening condition to land-appropriations. Early on in an unpopulated world it was easy enough to appropriate a plot of farmland while leaving vistas free for other aspiring farmers. But the growth of population has meant that, for some time now, there are people born who are not able to appropriate good farmland (or even just good places to build a home). One common response to this apparently inevitable failure of the non-worsening condition is to shift the focus from robust universalisability (leaving sufficient land for similar use and appropriation) to ensuring that one's appropriation does not worsen others' positions compared to their status prior to the appropriation. This move, widely attributed to Locke and more recently made explicit by Robert Nozick, is to ensure non-worsening by application of political economy. ${ }^{91}$ It is true that contemporary persons do not have verdant hills to appropriate for themselves, the thought goes, but they have other ways of making a living. Original appropriations of our forebears were and are legitimated provided that newcomers have as much opportunity for making a living off the available resources as persons had prior to the beginning of any regime of private property. ${ }^{92}$ There are two reasons this condition can be met in the face of increasing land-scarcity. First, greater technology, knowledge and

\footnotetext{
${ }^{90}$ ibid 47-56. Guibault notes the stark omission of consideration of this right in certain US copyright rulings: ibid 88 .

${ }^{91}$ Re Locke: see Sreenivasan n 11 above, 41-46, 102-105; Nozick, n 45 above, 175-180.

${ }^{92}$ This type of non-worsening is an important feature of many generally accepted rights: see Breakey, above n 67, §IV.2.
} 
know-how make each person's limited physical resources enormously more productive and efficient. Second, the development and distribution of substantial intellectual resources (ideas and information) grants people assets allowing them to make a living in modern market economies. These solutions appear to assuage the core of Locke's and Nozick's concern for the non-propertied until the accessibility and useability of those informational resources are themselves called into question. The more the access and use of those informational resources are controlled by intellectual property holders (as strong IPR, at least, would increasingly allow) the less the non-worsening proviso for tangible property is fulfilled. Again, strong IPR do not leave the original justifications for private property as they were.

Moving from questions of justifiability to the nature of private property itself, libertarian concerns arise with the capacity of even weak intellectual property rights to ride smoothly over the boundaries of tangible property. ${ }^{93}$ The advocate of reasonably strong private property rights in tangibles and land (and this does not include only the libertarian ${ }^{94}$ ) will find unacceptable a state of affairs where one person can, without your consent and across the boundaries of your private property, impose new duties upon you affecting your behaviour within and upon that property. ${ }^{95}$ For instance, if without your consent or consultation I drain

\footnotetext{
${ }^{93}$ In what follows I argue private property rights clash sharply with strong IPR. But there is a sense in which private property in tangibles, combined with rights to contract, can give rise to IPR-like institutions. See Breakey, n 50 above. However, such arguments justify only a minimal intellectual property regime, and necessarily leave substantial room for a thriving public domain.

${ }^{94}$ eg T. Kealey, Sex, Science and Profits (London: William Heinemann, 2008) ch 16; Burrell and Coleman, n 5 above, 183-187; see also R. Stallman's pointed Xerox anecdote in 'Why Software Should Be Free' (Free Software Foundation, 1992) [33]-[35] at http://www.gnu.org/philosophy/shouldbefree.html (last visited 10 August 2008).

${ }^{95}$ See Rothbard, $\mathrm{n} 86$ above, 749 . Note that unilateral appropriations of tangible property are accepted by the libertarian because the duties they impose do not affect actions within your own property; you are being 'left on your own' in the intuitive manner the libertarian prizes.
} 
the swamp in my land, and this benefits your neighbouring block of land enormously, the libertarian will be clear I can neither charge you for this benefit nor demand that you eschew using the improved land until you pay me for the improvements. ${ }^{96}$ You would not fully own your land (or indeed yourself) if I could, without your consent, impose enforceable new duties constraining your actions on your own property. Such duties may only be imposed by prior consent.

This inability to reap all the benefits arising from one's property follows the standard characterisation of property in law. As Penner describes, 'Although I may desire to capture all the benefits of my beautiful garden because it resulted from my use of my property, even those gained by passers-by that look upon it, the law of property will not help me to do so, for there is no duty on those passers-by not to look. ${ }^{97}$ Suppose a person sees an advertisement for a movie, listens to a publicly audible tune, watches a dance troupe, apprehends some building architecture, hears some argument, studies some new technological marvel from a distance, picks up others' transmissions on their radio, or notes another person's clever strategy. In all of these cases a person moving on public property, or even within their own property, receives information and ideas. If these new ideas come with duty-imposing-strings attached, then she may be subject to the creator's demands that she either pays remedies or avoids partaking of any benefits to her flowing from that idea. She can no longer control what she does on her own property because of the duties unilaterally foisted upon her.

Lysander Spooner's libertarian work on intellectual property is a paradigm of an inability to apprehend this conflict between tangible and intangible property rights. Spooner wishes to

\footnotetext{
${ }^{96}$ Nozick uses a similar point to mount a libertarian argument against Hart's Principle of Fairness; n 45 above, 90-95.

${ }^{97}$ n 27 above, 73; see also W. Gordon, 'An Inquiry into the Merits of Copyright: The Challenges of Consistency, Consent, and Encouragement Theory' (1989) 41 SLR 1343, 1357-1358.
} 
be absolutist about private property as well as allowing strong IPR. ${ }^{98}$ So, in line with the above swamp-draining case, he clearly stipulates that if I create wealth on someone else's property, then they - and not I - have rights to that wealth: 'If he be not the owner of the articles, on which he bestows his labor, he is not the owner of the additional value he has given to them; but gives or sells his labor to the owner of the articles on which he labors' ${ }^{99}$ Thus far, standard private property rights: prior consent is required for the foisting of duties. But when it comes to intellectual property Spooner allows property in ideas not only in cases where a person creates an idea in their own mind (ie on their own property) but also when the idea is publicised and now abides in other people's minds - that is, on their property. ${ }^{100}$

Strong property rights in tangibles are not compatible with even fairly weak intellectual property rights. They are not compatible because private property boundaries stand not only against physical interference but also, and crucially, against political interference - against the non-consensual imposition of enforceable new duties. This same fact about strong private property rights that the libertarian deploys to repel welfarist duties - that allows private property to fill the space of rights, as Nozick puts it ${ }^{101}$ - equally well repels the unilateral imposition of new duties required by intellectual property.

\footnotetext{
${ }^{98} \mathrm{n} 13$ above, ch I $\$ 4-5$.

${ }^{99}$ ibid ch I $§ 6$ [15]. Furthermore, Spooner lists plausible ways property can be lost (eg when one lets the air out of one’s lungs) without the owner's consent (ibid ch I $\$ 5$ [3]). This important possibility is ignored at the pivotal later moment when Spooner claims a man's property can only be lost by, 'an act of his will, namely, his consent to part with his right of property in it': ibid ch II $\$ 2$ [3].

100 ibid ch II $\S 2$ [1]-[3]. Spooner makes his case at this juncture seem more plausible by tending to discuss cases where the idea is being personally and directly communicated to a (presumably willing) other: eg ibid ch II $\S 2$ [10].

${ }^{101}$ Nozick, n 45 above, 238.
} 
A recent case in Canada exemplifies this incompatibility. In Schmeiser v Monsanto a farm-owner's crop became infected with patented genetically modified (GM) seed, probably from a neighbouring plot. ${ }^{102}$ The defendant apparently cultivated ${ }^{103}$ and replanted the GM seed the following season (thus reproducing the patented intellectual property), was sued by the patent owner, and subsequently found to be infringing. ${ }^{104}$ Both the decision at first instance and on appeal - consistent with the strict liability of patent law - did not accept as directly relevant to the patent infringement the question of whether the farmer was even aware of the presence of the GM seed in his crop. ${ }^{105}$ These decisions thus offered scant protection even to property owners qua innocent bystanders whose crops are unknowingly and even undesirably infected. ${ }^{106}$ In the final decision on the matter, the Supreme Court of Canada was willing to accept that the defendant's knowledge of the presence of the GM seed was indeed a relevant factor in the adjudication of patent infringement. ${ }^{107}$ Notwithstanding the protection this final decision offers innocent bystanders, the strong private property advocate must be dismayed at the entire trajectory of the court's thinking: in particular its pointed lack of recognition of the normative boundaries created by private property rights. ${ }^{108}$ 102 (2001) 202 FTR 78 (Federal Court of Canada - Trial Division); (2002) 218 DLR (4 $\left.4^{\text {th }}\right) 31$ (Federal Court of Appeal); [2004] SCC 34 (Supreme Court of Canada).

${ }^{103}$ Whether the seed was deliberately cultivated was disputed throughout by the defendant.

${ }^{104}$ While finding the defendant infringing, the Supreme Court judgment departed from the earlier rulings by not awarding remedies or court-costs to the claimant.

${ }^{105}$ R. Burrell and S. Hubicki, 'Patent Liability and Genetic Drift' (2005) 7 Environmental Law Review 278. ${ }^{106}$ R. Burrell and M. Lee, 'Liability for the Escape of GM Seeds: Pursuing the 'Victim'?' (2002) 65 MLR 517, $523-527$.

107 This welcome sensitivity by the SCC might not be easily transferred to other cases or jurisdictions, see Burrell and Hubicki, n 105 above, 281-284.

${ }^{108}$ Consider the court's brusque dismissal of the admixture argument defence: Burrell and Lee, n 106 above, $525-527$. 
The possibility that a property owner can be faulted for deliberately cultivating benefits arising innocently and occurring entirely on his own property is worrisome enough - that the burden might be shifted onto the property-owner to assiduously control the spread of GMseed infections from neighbouring plots in order to avoid infringing patents is beyond countenance. ${ }^{109}$ The libertarian should not be sanguine about the impotency of current private property rights in such debates, much less envisaging extensions to the means of their erosion.

Monsanto is a prime example of the capacity for patented material to swarm across property-borders - but the subjects of copyright are at least as disrespectful to such boundaries. Ideas, information and expressions continually flow back and forth across the boundaries of tangible property, and intellectual property duties inevitably flow with them. ${ }^{110}$ The first and third public domain provisions substantially constrain the extent of those duties (ideas-not-owned and fair-use ensure the duties only prohibit unprivileged acts of reproduction) and the second and fifth provisos limit the amount of ideational entities carrying intellectual-property-duties with them (idea-expression and sunsets ensure abstract, practical and old ideas are not fit subjects for copyright ${ }^{111}$ ). In many applications therefore, these four public domain limitations on intellectual property effectively serve as a direct

\footnotetext{
${ }^{109}$ The Supreme Court's approach indicates exactly such a shift. See Burrell and Hubicki, n 105 above, 283. ${ }^{110}$ Owners are entitled to use their private property rights (and powers of contract) to keep their ideas secret, of course. What copyright allows, that trade-secret does not, is for strings to be attached to ideas made public. ${ }^{111}$ Arguably, if the first three provisions were fully adopted, there may be grounds for holding that the substance of private property's resistance to imposed duties has been fulfilled, and that the temporal limitation of the fifth provision is therefore not necessary. Thanks to an anonymous reader for MLR for clarifying these and similar points.
} 
instantiations of private property's power to resist the unilateral impositions of duties across its borders. $^{112}$

But it is perhaps in the fourth provision that the commitment to private property in tangibles most directly asserts itself against the designs of strong IPR. The first-sale provision is nothing more than the insistence that those chattels in which intellectual property subsists must be treated - at least as far as sale, lending, sharing and giving is concerned ${ }^{113}-$ as if they were ordinary tangible pieces of property owned by the tangible-property holder. The first-sale provision mandates that the default status of most chattels will be determined by the law of private property - not that of intellectual property. Indeed, some of the inalienable private copying privileges protected in law seem to stem directly from appreciation of the prerogatives naturally due the owner of the physical object. ${ }^{114}$ In all, the nature and structure of private property boundaries provide powerful reasons to limit the scope, strength and duration of intellectual property in line with the five public domain provisions.

It is worth at this juncture briefly noting the libertarian position on free-speech. If the libertarian understands free-speech as a basic human right then such a commitment will straightforwardly motivate a robust public domain, as strong IPR prevent discussion and

\footnotetext{
${ }^{112}$ Strictly speaking, even with all of these public domain provisions respected, the libertarian still has cause for caution regarding intellectual property. Suppose I record your words either a) at a public performance, b) through the use of my radio-receiver, or c) through finding a discarded book or newspaper. If I own a computer and a printer then copyright prevents my use of my property in printing those words and selling those prints. In this way copyright empowers authors and performers to unilaterally impose new duties (beneficial to the performer/author) on listeners. Such duties control what the listeners can do on their own property. Libertarians have powerful reasons to be very careful about opening the door to any such impositions.

${ }^{113}$ Some types of public lending and rental (especially when potentially linked to subsequent copying) of chattels, such as CDs, are subject to intellectual property limitations.

${ }^{114}$ See Guibault, n 89 above, 106.
} 
critique of ideas - including cases where free-speech seems most crucial, concerning religious and political doctrines. ${ }^{115}$ But many libertarians do not see free-speech as basic, at least not in this sense. Rather, they contend that free-speech rests upon prior private property rights. ${ }^{116}$ People in their own sovereign spheres have a right to say what they will. But once we observe the way information and inspiration freely permeate physical property boundaries we see that even a libertarian who defends free-speech in this derivative way has reason to deny strong IPR. As noted above, even quite weak intellectual property rights require that an owner, who has learned something (while remaining within his own property), is not allowed to communicate it to others (even if they are all on his property). On either understanding of free speech then, strong IPR are unacceptable to the libertarian.

Our final concern focuses on the libertarian commitment to self-ownership. While the clash between tangible and intangible property rights is real enough, it is perhaps not entirely clear why the libertarian must support tangible property. Why may they not - arguendo, at least - allow primacy to rights over intangibles, and then have rights to tangibles fill the remaining space? The reason the libertarian must commit to tangibles is that they will perceive a qualitative difference between the ways the two types of rights interact with selfowners. $^{117}$

\footnotetext{
${ }^{115}$ See Netanel, n 31 above.

116 eg M. Rothbard, For a New Liberty: The Libertarian Manifesto (New York: Libertarian Review Foundation, Rev ed, 1978) 43; J. Hospers, 'What Libertarianism Is' in T. Machan (ed) Liberty for the Twenty-First Century: Contemporary Libertarian Thought (Lanham, Md: Rowman \& Littlefield, 1995) 9-10.

${ }^{117}$ Palmer, n 11 above, 831. The following two paragraphs attempt to tease out the thrust of Palmer's contention that tangible property rights merely 'restrain action' while intellectual property rights 'restrict liberty' - as against Gordon's apt riposte that, 'all entitlements limit each other' (n 97 above, 1423). I do not confront Gordon's point per se. I merely argue the libertarian has compelling reasons to side with Palmer.
} 
Granting rights over some tangible object takes a physical thing out of the free-space a person is at liberty to live in or interact with. While that is not a trivial thing to do, the appropriation is nevertheless physically bounded, and so it does not immediately and irrevocably affect all other physical bodies - including human bodies. So there is a reasonable sense to the thought that property rights in tangible things are not rights in human bodies. They are still constraints on your actions, in the sense that they constrain where you can go, but there is no ongoing restriction regarding what you can do with your body itself, just considered on its own. You still get to fully control your own actions where you, for instance, are on public land, or are invited onto a friend's property, or are on your own property. In all of those cases my property right constitutes no abridgement of your right over your own body; it cannot stop you dancing, or speaking, or building. ${ }^{118}$ In this sense my physical property rights - my normative claims regarding you and all others - are bounded physically. They are localised, and because your body also has a location you can be in a position where my rights cannot control you - they cannot, as it were, touch you. But intellectual property rights are not localised - there is simply no getting away from them in this sense.

Another way of putting this point is to begin by asserting, as the natural rights libertarian does, that all people own their bodies as fully as a person can own any thing. ${ }^{119}$ We then begin thinking about how to assign normative relations with the rest of the world, given this initial commitment. ${ }^{120}$ One way of keeping to this initial commitment might be to erect

\footnotetext{
${ }^{118}$ Palmer, n 11 above, 827-828.

${ }^{119}$ See Rothbard, n 116 above, 28; G. Cohen, Self-Ownership, Freedom and Equality (Cambridge: CUP, 1995) 72, 213, 240; Arneson, n 39 above, 36-40.

${ }^{120}$ Both Locke and Kant seem to utilise this trajectory. Locke, n 4 above, Bk I §27; Kant, n 68 above, 337-338, 343-344. We should however be cautious in reading the modern notion of property into their statements of selfownership. See L. Underkuffler, ‘On Property: An Essay’ (1990-1991) 100 YLJ 127.
} 
property boundaries across the land. So long as these boundaries do not cut across or overlap any person's physical body, we have not violated our initial commitment. Contrariwise, one way not consonant with our initial commitment is to assert that one person (the Inventor) can order everyone else not to copy his publicly visible actions. For doing so immediately gives the Inventor rights over the ways other people can use their bodies; which cannot be done ex hypothesi. $^{121}$

To be sure, there are alternative, less libertarian, construals of self-ownership to be found in early natural rights theories. While our specific focus here is on observing the reasons the libertarian will reject strong IPR, it is nevertheless worth pointing out these earlier conceptions of self-ownership are equally unsympathetic to strong IPR. As noted previously, the possibility that a community can impose duties on others prior to their attaining their maturity through the very process of education allowing them to attain that maturity effectively dissolves the freedom and independence classical self-ownership aims to vest in all persons. ${ }^{122}$ Similarly, there has since Locke been a tight link between self-ownership and a right to labour and its tangible fruits. But all physical labour rests upon a superstructure of learned ideas, copied skills and created tools. ${ }^{123}$ If this intellectual scaffolding is owned by prior individuals, then contemporary persons do not have the property in labour Locke explicitly set out to defend as an essential aspect of their self-ownership. Perhaps the most important message of Locke's First Treatise was that prior property claims cannot abridge

\footnotetext{
${ }^{121}$ Note, however, that self-ownership on its own (on this construal) does not justify the fourth provision - firstsale.

${ }^{122}$ See text to nn 44-45 above.

${ }^{123}$ Indeed, the very plant seeds and animal breeds persons need to farm are prior creations of individuals. It is easy to forget natural (ie wild) grains and legumes are quite unsuited to farming. The grains commonly used by contemporary farmers were deliberately cultivated and bred, probably circa $8000 \mathrm{BC}$. A similar story holds for domesticated animals. Kealey, above n 94, 34-35.
} 
each self-owner's right to labour productively and so to sustain and govern their lives. If a direct edict from God vesting Adam with property in the entire world will not suffice to dissolve later persons' substantive rights to labour on the world, then there is no hope whatsoever for intellectual property to effect the same result. ${ }^{124}$ Ultimately, strong IPR are as incompatible with classical Lockean self-ownership as they are with modern libertarian selfownership.

In summation, the libertarian's initial flirtation with strong IPR may be understandable, but when we examine the duties and impositions required by strong IPR, we see the attraction cannot harden into commitment. The nature of intellectual property is to justify interference; it is to infringe the basic libertarian view that persons should be left alone. ${ }^{125}$ Having even one of the free-market, private property (its justification or its substance), free-speech or selfownership threatened by strong IPR would be sufficient reason for the libertarian to reject it. Faced with violations of all four of these bedrock commitments, the libertarian rejection of strong IPR is thoroughly over-determined.

\section{Conclusion}

Before finishing, one final argument. I hope by the weight of the foregoing arguments to have shown that no existing natural rights theory allows strong IPR. But here I want to briefly press towards a stronger conclusion again - that there is no viable potential natural rights theory that could do so. Speaking generally, given the primacy of the above concerns within

\footnotetext{
${ }^{124}$ Locke accepts this antecedent arguendo from Filmer: Locke, n 4 above, Bk II. §§41-42.

${ }^{125}$ Libertarian theorists emphasising the role of natural rights as social mechanisms for resolving interpersonal conflicts will thus find intellectual property at least as undesirable as positive welfarist rights. See, eg, the discussion of positive rights and social peace in J Hasnas, 'Toward a Theory of Empirical Natural Rights?'
} (2005) 22 Social Philosophy and Policy 111, §B [10]-[13]. Palmer explicitly deploys this line of thought against intellectual property: n 11 above, 856-861. 
natural rights thinking, it should be clear how unlikely, counter-intuitive and unrecognisable any yet-to-be-articulated natural rights theory would have to be if it were to make room for strong IPR. The adduced considerations suggest any potential wedding of natural rights with strong IPR is likely to be so far removed from the cluster of commitments central to natural rights thinking that it will barely be worthy of the appellation.

More specifically, allow me to put into different terms the philosophical fork offered by the arguments of the foregoing two sections. If the natural rights theory in question holds that rights protect morally important interests (as with the modern Interest theory of rights) then robust universalisability is almost certainly required. ${ }^{126}$ As the interest is as morally important to one person as the next, it would be counterproductive to allow one person's exploitation of the opportunity intentionally protected by some right to systematically undermine other's similar opportunities. ${ }^{127}$ If, alternatively, the theory asserts that rights are powers of making choices (the Will or Choice theory of rights ${ }^{128}$ ) then there will be good reason to protect zones wherein a person's choices can be regent. ${ }^{129}$ This creation of 'a realm of jointly possible domains of autonomy ${ }^{130}$ will be constituted by self-ownership and powerful private property rights. ${ }^{131}$ Ultimately, whether natural rights are best understood as protecting key interests or securing domains of free choice, the logic in either case ensures there is no space remaining for strong IPR.

\footnotetext{
${ }^{126}$ See nn 70-71 above, and accompanying text.

${ }^{127}$ Especially if there is a viable alternative that does not undermine such future opportunities. See Breakey, $\mathrm{n}$ 67 above, §IV.1.

${ }^{128}$ See H. Hart, Essays on Bentham (Oxford: Clarendon, 1982) 183-188.

${ }^{129}$ I. Berlin, 'Two Concepts of Liberty' in Four Essays on Liberty (London: OUP, 1969) 121-127.

${ }^{130}$ N. Simmonds, 'Rights at the Cutting Edge' in M. Kramer, N. Simmonds and H. Steiner (eds) A Debate over Rights: Philosophical Enquiries (New York: Clarendon, 1998) 126.

131 eg H. Steiner, An Essay on Rights (Oxford: Blackwell, 1994).
} 
But why should we think the two alternatives (the Interest and Will theories) proffered in the above fork are exhaustive of the options - at least as far as natural rights theories are concerned? One answer is that each alternative offers a sheet anchor to prevent outlandish claims for natural rights being entertained. Consider what prevents someone asserting that, as first person in a country, they have invested much time and ingenuity in setting up a 'statereligion' for that country. Moreover, they contend, any subsequent immigrant must respect their rights (to the labour and personality invested in the project) and hence refrain from interfering with this prior project. ${ }^{132}$ That is, the immigrant must leave or convert.

My question here is not the easy question of why this right is not accepted by any current natural rights schema, but rather why we might think that such a right could not possibly fall within the compass of natural rights thinking at all. It seems to me there are two reasons why founding state religions simply cannot be a natural right. First, the right is not robustly universalisable. It does not allow others coming later to have the same opportunities. Second, the right, and its accompanying duties, is not localised. It is therefore able to cut across and into the lives and actions of other persons. Such rights do not leave other persons free to do what they will in their own space and with their own bodies. In sum, the two factors of robust universalisability and self-ownership/private property play pivotal roles in shaping natural rights. ${ }^{133}$ They each play this role because both factors are ways of delineating and delimiting interference. Robust universalisability limits our capacity to perform actions interfering with others' similar actions by our imposing new duties on them. And self-ownership emphasises that, when it comes to considering what counts as interference, we do not start with a blank

\footnotetext{
${ }^{132}$ Note this right is universalisable in a 'first-come, first-served' manner; the state-religion-founder could consistently maintain that if any other person had been first-settler in the country, they could have been the one to begin this project and so found a state-religion.

${ }^{133}$ As we might expect therefore, the libertarians noted earlier for eschewing robust universalisability (see n 82 above) explicitly endorse self-ownership. Narveson, n 38 above, 206; Feser, n 82 above, 56.
} 
slate - but that the human body, and the space and physical resources immediately surrounding it, is the ongoing locus of basic human activity.

If I am right about the lynchpin role of these two factors then strong IPR is, when it comes to natural rights, relevantly analogous to the founding of a state religion. Cutting across selfownership and the boundaries of private property, and systematically undermining the future opportunities of others to do likewise, strong IPR are anathema to the most basic machinery of natural rights thinking.

To conclude: natural rights theory is not one specific position, but a constellation of interrelated perspectives. It includes right-libertarianism and left-libertarianism, as well those hearkening back to the classical liberals and the natural law tradition. Such theories may be based around a conception of rights as morally protected interests, or alternatively as protecting zones of free choice. At various points in this paper I argued each and every one of these positions have internal reasons to respect the public domain. The most basic machinery of natural rights - commitments such as non-interference, fairness, non-worsening, universalisability, prior consent, self-governance, and the establishment of zones of autonomy - all justify a robust public domain. Ex fortiori, there are further commitments which, while not conceptually lynchpin, are nevertheless widespread in natural rights theories. Under this rubric we might include the right to free speech, the right to privacy, concerns about large-scale inequalities of inherited power, the encouragement of independent, entrepreneurial activities, distaste for large-scale bureaucracies, a broad approbation of the free-market, and a commitment to the development of science, learning, reason and culture. These factors severally and in concert press further against the acceptability of strong IPR. 
In view of these myriad factors, I conclude that no theory of natural rights can accept strong intellectual property rights. Natural rights stand as a bulwark against utilitarian or egalitarian dissolution of the claims of a person's life and labour, but - if the above arguments are cogent - they equally stand against strong intellectual property rights. When it comes to the constellation of natural rights theories, there is no star justifying undermining the public domain. 